\title{
Hazard assessment investigations in connection with the formation of a lake on the tongue of Unterer Grindelwaldgletscher, Bernese Alps, Switzerland
}

\author{
M. A. Werder ${ }^{1}$, A. Bauder ${ }^{1}$, M. Funk ${ }^{1}$, and H.-R. Keusen ${ }^{2}$ \\ ${ }^{1}$ VAW, ETH Zurich, 8092 Zurich, Switzerland \\ ${ }^{2}$ GEOTEST AG, Birkenstrasse 15, 3052 Zollikofen, Switzerland
}

Received: 14 March 2009 - Revised: 9 November 2009 - Accepted: 7 January 2010 - Published: 11 February 2010

\begin{abstract}
The surface of Unterer Grindelwaldgletscher glacier tongue has subsided by more than $200 \mathrm{~m}$ over the last 150 years. The surface lowering is not uniform over the glacier tongue but depends on the thickness of the uneven debris cover, which led to the formation of a depression on the tongue. A lake can form in this basin, which occurred for the first time in 2005. Such a glacier lake can drain rapidly leading to a so-called outburst flood. The lake basin has been increasing in size at an alarming rate and in 2008, it reached a volume which poses a significant flooding threat to the communities downstream, as was exemplified by an outburst of the lake in May 2008. The future evolution of the lake basin was extrapolated based on surface lowering rates between 2004-2008. An outburst flood model was tuned with the measured hydrograph from 2008 and then was run with the extrapolated lake bathymetries to simulate future lake outbursts and estimate their flood hydrographs. We discuss the rapidly increasing risk for Grindelwald and other communities, as well as the installation of an early warning system and possible prevention measures.
\end{abstract}

\section{Introduction}

Glacier lake outburst floods, also known as jökulhlaups, commonly occur in glaciated regions around the globe and present one of the greatest and most far-reaching glacierrelated hazards. Lakes dammed by ice have a tendency to drain rapidly once an initial drainage pathway has been established (Roberts, 2005; Tweed and Russell, 1999), leading to floods in the valleys downstream. The outburst of such

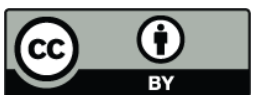

Correspondence to: M. A. Werder (werder@vaw.baug.ethz.ch) glacier lakes have caused extensive damage in the Swiss Alps (Raymond et al., 2003; Haeberli, 1983; Röthlisberger, 1981). The existence and development of these lakes is closely linked to the evolution of their damming glacier. Thus, in times of rapid glacier change, it must be expected that some of these lakes will cease to exist, others will change their behaviour and new ones will emerge.

The tongue of Unterer Grindelwaldgletscher (Fig. 1) is covered with an uneven layer of debris. The layer is thicker towards the terminus due to the ongoing collapse of an unstable rock face located there, with the result that the surface lowering rates are higher upglacier than right at the terminus. This led to the development of a topographical depression where a lake started to form in 2005. This basin has been growing in size ever since and poses an increasing threat to the communities downstream as the lake, which it can contain, potentially drains rapidly and causes floods. To make a hazard assessment of the situation, we looked at the future development of the glacier tongue and estimated future lake volumes. With these estimates, we calculated the expected peak discharges and advance warning times of such floods. These calculations were done with an existing model of glacier outburst floods (Clarke, 2003). The validity and limitations of our model results are discussed, as well as the implications of our findings for the damage potential to Grindelwald and communities further downstream, and possible preventative measures.

\section{Methods}

The surface topography of the glacier tongue was established with photogrammetric methods from aerial photos taken in autumn of 2006, 2007 and 2008, with an error of $\sim 0.1 \mathrm{~m}$. From the resulting digital elevation models, the bathymetry of the lake basin was calculated and, thus, the potential lake

Published by Copernicus Publications on behalf of the European Geosciences Union. 


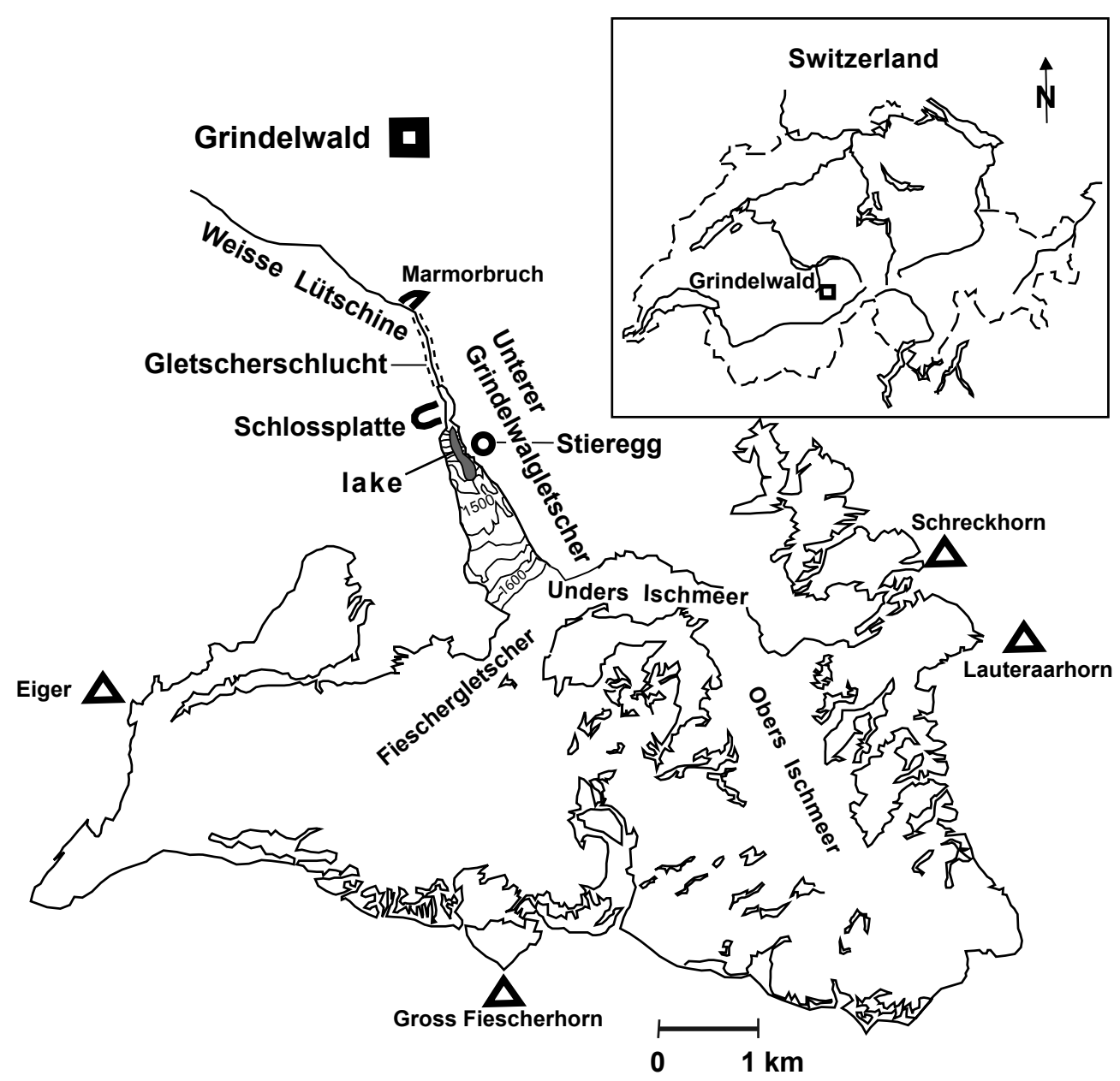

Fig. 1. Map of Unterer Grindelwaldgletscher with its two tributaries: Fieschergletscher (left) and Unders Ischmeer/Obers Ischmeer (right). The lake is located just south of "Schlossplatte" on the tongue of the glacier.

volume. The bed topography was determined with ground penetrating radar (VAW, 2007); six profiles were acquired between the lower reaches of the lake to $\sim 1 \mathrm{~km}$ upglacier (Fig. 6a between 2150 and $3000 \mathrm{~m}$ ). As radar measurements were not possible on the glacier tongue lying in the gorge, we interpolated the bed between the ice free part of the gorge and bed further upglacier, as determined by radar. We estimate that the presented bed topography has an error of $\pm 10 \mathrm{~m}$ where it was determined by radar and larger elsewhere.

The stage of the proglacial river was measured at Marmorbruch (Fig. 1), ca. $1.4 \mathrm{~km}$ below the glacier terminus with a radar. A stage-discharge relation was established with dye dilution methods, however, as the cross-section of the river bed is constantly changing, the error in the calculated discharge is around $20 \%$. The lake level was measured with a pressure transducer installed in the lake. The main error source is the vague known location of the sensor. Together with the bathymetry a lake discharge can be calculated for which we estimate an error of $20 \%$.

\section{Field site}

The two glacier branches of Obers/Unders Ischmeer (between Schreckhorn and Fiescherhorn) and Fieschergletscher (between Fiescherhorn and Eiger) come together at the Zäsenberg to form Unterer Grindelwaldgletscher (Fig. 1). With a surface area of $19.6 \mathrm{~km}^{2}$, it is the sixth largest glacier in Switzerland (status year 2004).

The evolution of Unterer Grindelwaldgletscher (Fig. 1) has been documented in a great number of historical illustrations and paintings dating back as far as the 17th century. The oldest illustration is a copperplate engraving (etching), done by J. Plepp before 1642 (Zumbühl, 1980). Since 1880, the position of the tongue has been determined every year until 1983, when it became impossible to take measurements as the terminus had retreated into the Gletscherschlucht, a deep and narrow gorge (Glaciological reports). Volume changes have been determined from 1861 onward based on the Siegfried and Dufour maps, and other maps and aerial photographs 
from the years that followed (Steiner et al., 2008). According to these findings, Unterer Grindelwaldgletscher lost $\sim 1 \mathrm{~km}$ in length and $\sim 1.56 \mathrm{~km}^{3}$ in volume, equivalent to $60 \mathrm{~m}$ ice thickness loss on average over the entire glacier surface (Fig. 2).

\subsection{The unstable rock face at the Schlossplatte}

The surface lowering of the glacier tongue by more than $200 \mathrm{~m}$ since the little ice age exposed its flanking valley sides leading to their destabilisation due to the cessation of ice pressure. Consequently, at the Schlossplatte, $\sim 2 \times 10^{6} \mathrm{~m}^{3}$ of rock on the left side near the glacier terminus have become unstable (Figs. 1 and 3).

From July 2006 to August 2008, the rock face moved forward a distance of $51 \mathrm{~m}$. During this two-year period, most of the moving rock mass disaggregated and repeatedly triggered rockfalls (Fig. 4). The debris remained on the glacier surface, with some of it spilling into the gorge in the proglacial area. By this process, the debris layer in the terminus zone of the glacier has been increasing in thickness. The slip plane of the unstable rock face lies at an unknown depth underneath the current glacier surface level, with a downward slope angle of $\sim 38^{\circ}$ (source: GEOTEST, Oppikofer et al., 2008). In future, the remaining rock mass will probably continue to move towards the east side of the valley, but at a decreasing rate because of its further disaggregation (Fig. 4b).

\subsection{Surface changes in the terminus zone since 2000}

The tongue of Unterer Grindelwaldgletscher is located below $1500 \mathrm{~m}$ a.s.l. The inflow of glacier ice from the upper region has diminished drastically in the past decades due to higher summer temperatures and negative mass balances. The surface elevation of the glacier tongue has been dropping at an average rate of $5 \mathrm{~m} \mathrm{a}^{-1}$ since 2000 , translating into a volume loss of $\sim 3$ million $\mathrm{m}^{3} \mathrm{a}^{-1}$ of ice between 2000 and 2008 (Fig. 5). It can be seen that the surface lowering is not uniform, which we attribute to the uneven debris layer on the glacier tongue. Direct point measurements and visual observations show that the debris layer is several meters thick near the Schlossplatte and 0-30 cm further upglacier. For debris layers thicker than a few centimetres, it was observed (Lundstrom et al., 1993) that the thicker the debris layer, the lower the rate of ablation of the underlying ice; with a $40 \mathrm{~cm}$ thick layer, ice ablation is reduced by $95 \%$. It is evident (Fig. 5) that the glacier surface elevation remained largely unchanged in the area below the unstable rock face (northern part of the tongue), whereas upglacier it lowered very rapidly. This led to the formation of a depression on the glacier tongue. The ice flow in the lower region of the tongue appears to have been minimal (only a few $\mathrm{m} \mathrm{a}^{-1}$ ) in recent years, also favouring the formation of depressions on the glacier surface.

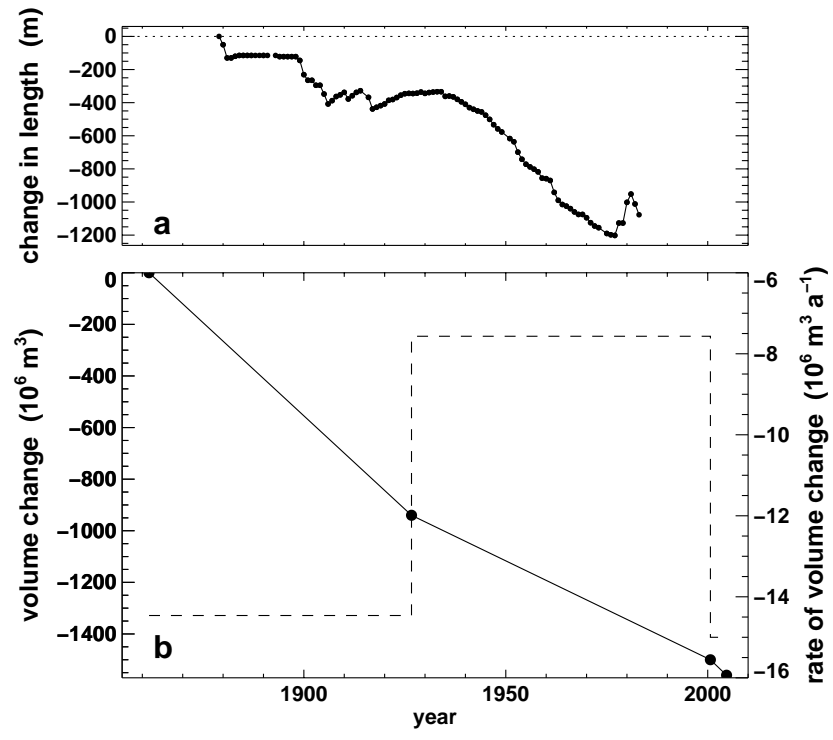

Fig. 2. Changes in length since 1880 (a), volume (b, solid line) and rate of volume change (b, dashed line) since 1860 of Unterer Grindelwaldgletscher. The terminus retreated into an inaccessible deep gorge and it has not been possible to determine its position since 1983 (Bauder et al., 2007; Steiner et al., 2008).

\subsection{Gorge geometry and terminus location}

The terminus of Unterer Grindelwaldgletscher is situated in a long and narrow gorge, the Gletscherschlucht (Fig. 1). This gorge was explored on foot in March 2007. It was found that up to $\sim 1 \mathrm{~km}$ (as measured from the gorge entrance) it has a width of $10-30 \mathrm{~m}$ then narrows to a width of only $2-$ $3 \mathrm{~m}$ at the $1.4 \mathrm{~km}$ point (Fig. 6). It was possible to proceed for another $\sim 15 \mathrm{~m}$ beyond a local snow-ice formation, where the gorge narrowed to $\sim 0.5 \mathrm{~m}$ in width, prohibiting further progress. Here, at Point PA (km 1.435, Fig. 6), there was no ice and no sign of the glacier terminus. The stream flow in the gorge could be clearly identified up to P1 ( $\mathrm{km} \mathrm{1.271)}$ in our photogrammetric evaluations. The glacier terminus visible on the aerial photographs from autumn 2006 is designated as P2 (at km 1.510). The most likely glacier terminus (debris-covered or unrecognisable in the gorge) lies between $\mathrm{P} 1$ and $\mathrm{P} 2$. The floor of the gorge was ice-free up to the point reached at PA (between points $\mathrm{P} 1$ and $\mathrm{P} 2$ ). The length and the geometry of the remaining ice-free gorge floor is not known, as it could not be explored further. The same is true regarding the topography of the still ice-covered part of the gorge at the front section of the glacier tongue. It is only beyond the Schlossplatte that data on the glacier bed is available, based on our radar measurements (VAW, 2007). 


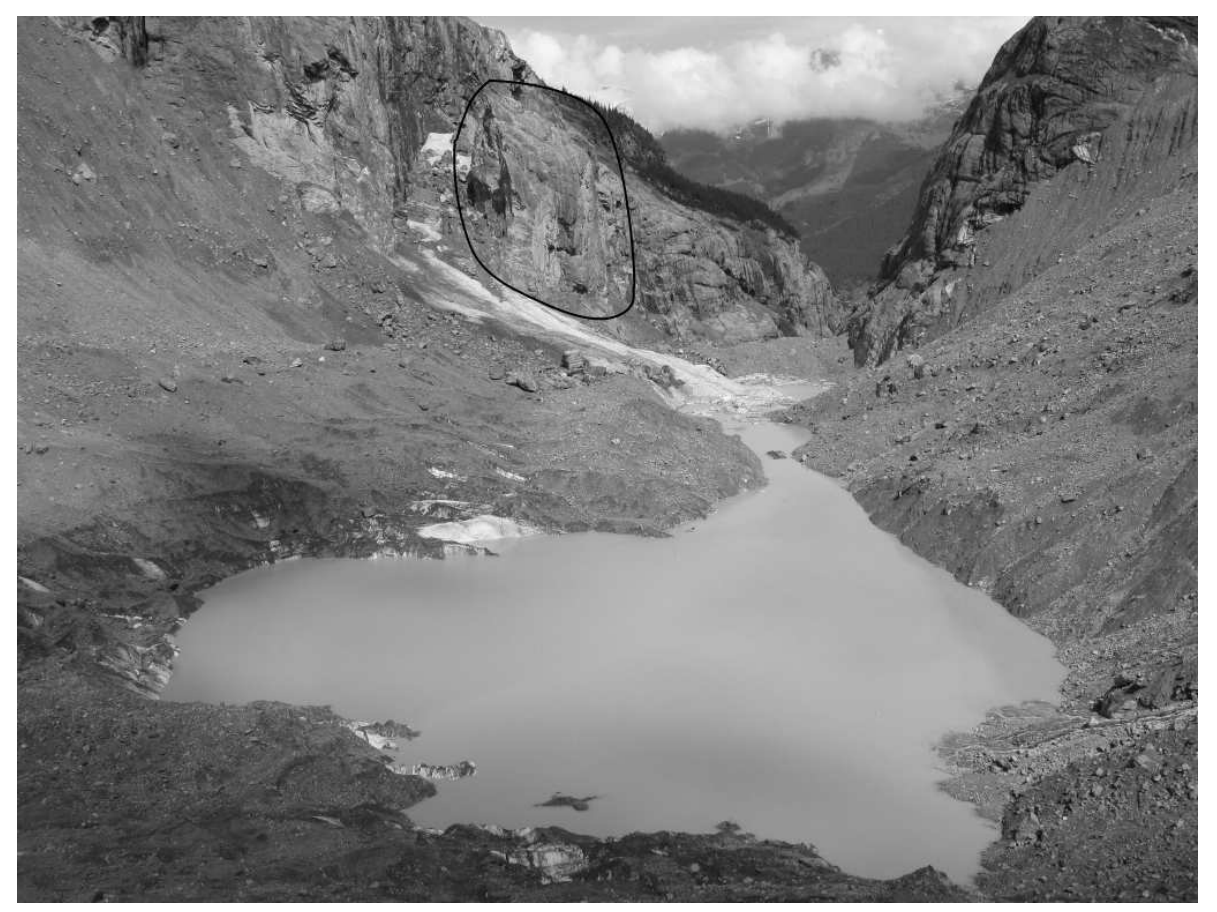

Fig. 3. The unstable rock face (Schlossplatte, marked) on the orographic left side of Unterer Grindelwaldgletscher at the foot of the eastern ridge of the Eiger mountain, the debris-covered tongue and the supraglacial lake in May 2008.
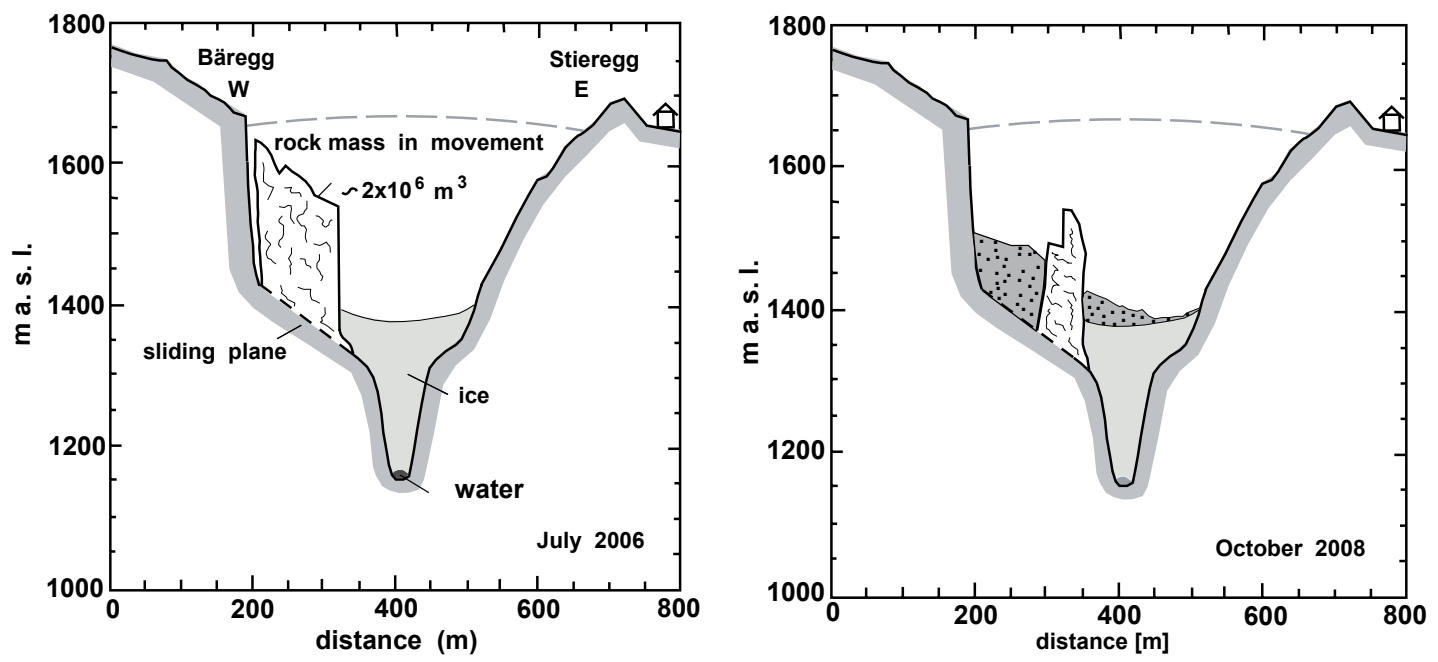

Fig. 4. Evolution of the unstable rock mass since July 2006. The lowest point of the glacier bed geometry was interpolated between the icefree surface topography immediately downstream and results from radio-echo soundings performed upstream. However, the cross-section of the glacier and location of the sliding plane are not known.

\section{Lake development}

The thinning of the tongue of Unterer Grindelwaldgletscher has been non-uniform due to the uneven thickness of the debris cover leading to the formation of a topographical depression on the tongue of the glacier where water can accumulate and form a lake (Fig. 3) (cf. Gulley and Benn, 2007; Benn et al., 2001). The lake formed for the first time in 2005 and its basin has grown in size ever since (Table 1 and Fig. 7). The area and volume of this basin was determined based on measurements of surface topography. Its content corresponds to the maximal potential lake volume if the basin is filled completely. The photogrammetric analysis of aerial photographs 


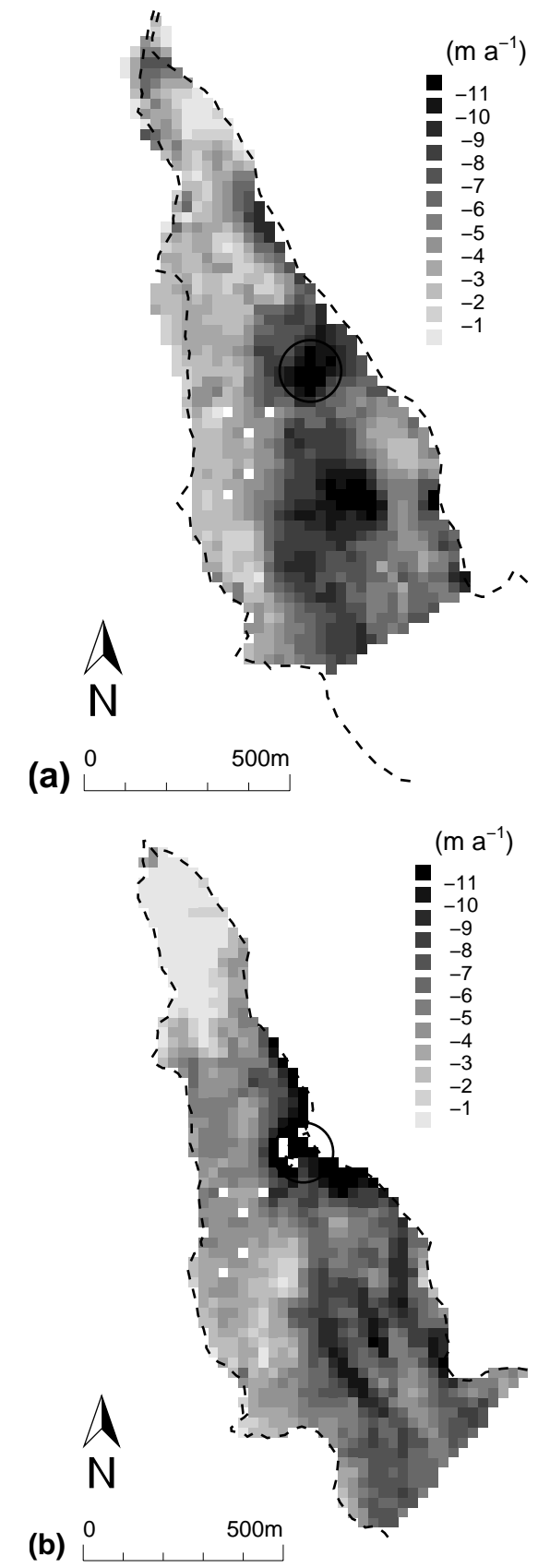

Fig. 5. Thickness changes on the tongue of Unterer Grindelwaldgletscher in the years $2000-2004\left(\overline{\Delta h}=-5.41 \mathrm{~m} \mathrm{a}^{-1}, \mathbf{a}\right), 2004$ $2008\left(\overline{\Delta h}=-5.25 \mathrm{~m} \mathrm{a}^{-1}, \mathbf{b}\right)$. The deepest point of the newly formed lake is marked by a circle.

taken at the end of summer in the years 2006, 2007 and 2008 allowed the determination of the potential lake size in spring of the following years (Fig. 7 and Table 1). The subsidence of the ice surface in the lake basin is faster than on the rest of the tongue (Fig. 5), thus, further accelerating the growth of the lake basin. This faster ablation of submerged ice is probably

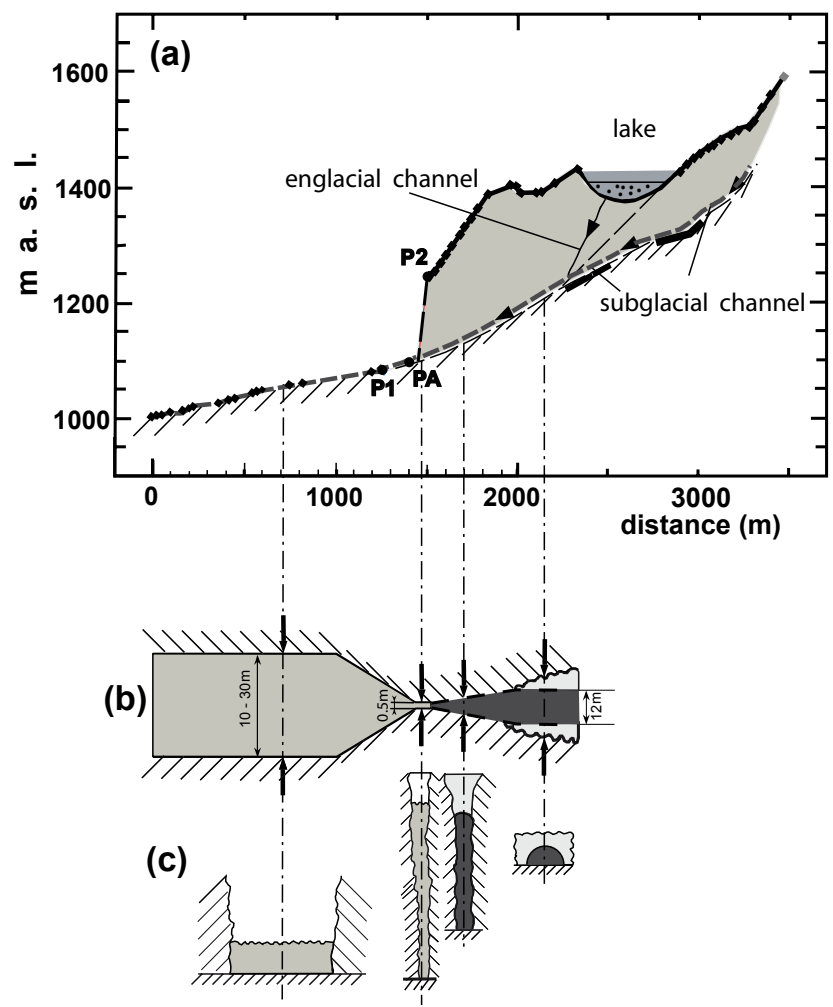

Fig. 6. Longitudinal profile of the glacier, the lake and the gorge (a), map plane view (b), and four cross-sections of the gorge (c), all share the same horizontal axis with distances measured from the lower terminus of the gorge. (a) The arrows indicate the en- and subglacial flow path of the water. Point P1: up to here it was possible to identify the stream bed clearly on the aerial photographs, but not further upstream. Point P2: glacier ice is visible on aerial photographs, but not further downstream. PA: it was possible to conduct reconnaissance of the gorge this far. The bed is marked with a thick line where it is known from radar measurements. (b) Schematic map view of the gorge: up to point PA mapped and thereafter an educated guess. (c) Diagram of the water flow at the glacier bed and in the gorge in four cross-sectional views. The dark-grey coloured water indicates subglacial pressurized flow conditions. Free surface runoff takes place beyond the glacier terminus, indicated by lightgrey coloured water. The geometry of the two right cross-sections is an educated guess.

due to two effects, water can conduct heat efficiently by convection through a debris layer due to its density anomaly, furthermore, the debris on steeper slopes is washed away by the water, exposing bare ice. Conversely, the ice ablation in the vicinity of the unstable rock face at the terminus is negligible due to the thick debris cover which has led to the gradual formation of an ice dam in the years 2005-2009. In fact, the dam elevation has even increased between 2007 and 2009 due to the thickening debris cover caused by the ongoing collapse of the Schlossplatte (Table 1). 

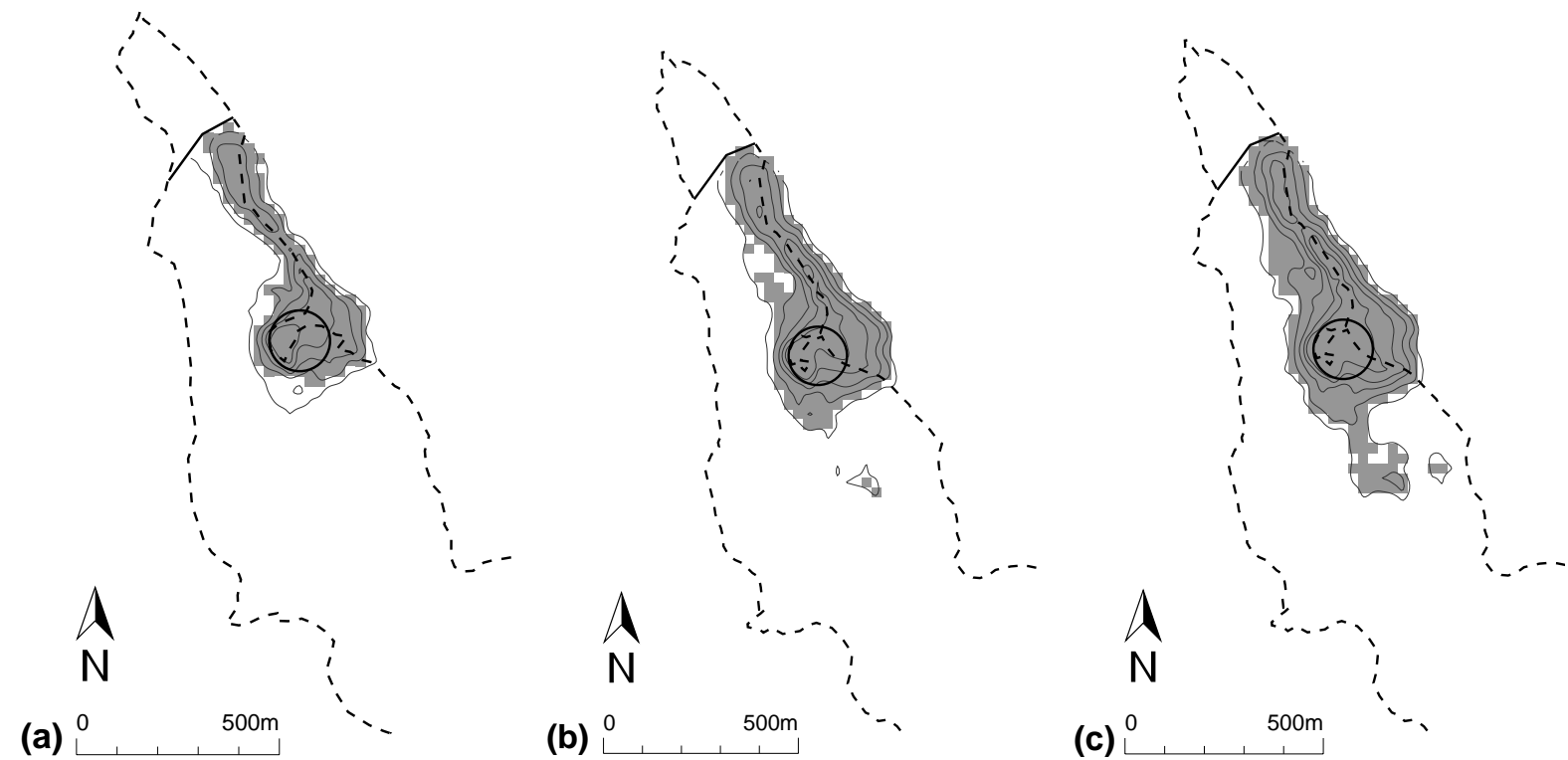

Fig. 7. The gray-shaded area gives maximal lake extent for the years $2007\left(\mathbf{a}, 0.034 \mathrm{~km}^{2}\right), 2008\left(\mathbf{b}, 0.092 \mathrm{~km}^{2}\right)$ and $2009(\mathbf{c}, 0.136 \mathrm{~km})^{2}$. The lake depth is given by the contour lines inside the lake area (interval $10 \mathrm{~m}$ ). The centre of the lake is marked by a circle (identical to Fig. 5), the lake dam by a solid line and the glacier outline by a dashed line.

Table 1. Dam crest elevation $h_{\text {dam }}$, lake basin surface area and volume for the years 2007, 2008 and 2009 based on the surface topography determined from aerial photographs taken in fall of the previous year. "Year": summer season for which the indicated lake size was determined, "Survey": date when the aerial pictures were taken.

\begin{tabular}{rrrrr}
\hline Year & $\begin{array}{r}\text { Survey } \\
(\text { date })\end{array}$ & $\begin{array}{r}h_{\text {dam }} \\
(\mathrm{m} \text { a.s.1. })\end{array}$ & $\begin{array}{r}\text { Surface area } \\
\left(\mathrm{km}^{2}\right)\end{array}$ & $\begin{array}{r}\text { Volume } \\
\left(10^{6} \mathrm{~m}^{3}\right)\end{array}$ \\
\hline 2007 & 5 Sep 2006 & 1396.6 & 0.034 & 0.24 \\
2008 & 12 Sep 2007 & 1402.3 & 0.092 & 1.30 \\
2009 & 18 Aug 2008 & 1407.3 & 0.136 & 2.61 \\
\hline
\end{tabular}

Due to ongoing climatic warming, Unterer Grindelwaldgletscher will continue to lose mass and become thinner, particularly in the region of the glacier tongue. Ablation will continue to occur at a non-uniform rate due to variations in the debris-layer thickness. There will be barely any melting of the ice dam near the terminus of the glacier tongue due to the thick layer of debris. In contrast, the rest of the tongue will become thinner at the rate of $5-10 \mathrm{~m} \mathrm{a}^{-1}$, as observed between 2004 and 2008. By extrapolating the local surface lowering rates, shown in Fig. 5b, we predict the geometry of the future glacier tongue and, thus, an estimate of the future lake basin volume and bathymetry can be calculated. It shows that the volume will increase from $2.6 \times 10^{6} \mathrm{~m}^{3}$ in 2009 to an expected $8.9 \pm 1.8 \times 10^{6} \mathrm{~m}^{3}$ in 2014 . Table 2 summarises the expected basin volumes for the years 2010-2014.
Table 2. Predicted lower bound on the future lake basin surface area and volume for the years 2010-2014 for a dam crest elevation of $h_{\text {dam }}=1407 \mathrm{~m}$ a.s.l.

\begin{tabular}{rrr}
\hline Year & $\begin{array}{r}\text { Surface area } \\
\left(\mathrm{km}^{2}\right)\end{array}$ & $\begin{array}{r}\text { Volume } \\
\left(10^{6} \mathrm{~m}^{3}\right)\end{array}$ \\
\hline 2010 & 0.17 & 3.5 \\
2011 & 0.21 & 4.5 \\
2012 & 0.24 & 5.7 \\
2013 & 0.28 & 7.3 \\
2014 & 0.30 & 9.0 \\
\hline
\end{tabular}

\section{Glacier dammed lake outburst floods}

Glacier dammed lakes tend to empty suddenly and the resulting flood can inflict terrible damage on the valleys below. Lake dam failure can occur via two processes, either by flotation of the ice dam or by enlargement of a small dam breach (e.g. a crack) into a channel (Roberts, 2005). The first process can occur because the density of ice $\left(900 \mathrm{~kg} \mathrm{~m}^{-3}\right)$ is smaller than that of water $\left(1000 \mathrm{~kg} \mathrm{~m}^{-3}\right)$. Thus, once the filling level reaches around $9 / 10$ of the ice dam height, the dam can be lifted and the water can escape. The second process is caused by the progressive enlargement of an en- or subglacial channel due to the dissipation of potential energy and the positive temperature of the conducted water. The model we used to predict flood magnitudes simulates the second process and will be discussed in the following section. 


\subsection{Modelling hydrographs}

Nye (1976) offered the first theory explaining the drainage mechanism of glacier dammed lakes. This work was extended mainly by Spring and Hutter (1982), Clarke (2003) and Flowers et al. (2004). Even though the model we use is based on the Spring-Hutter equations, for illustration, we give a brief introduction to the simpler Nye (1976) model for which $\mathrm{Ng}$ and Björnsson (2003) derived an approximate solution. The rate of change in discharge with time $\frac{d Q}{d t}$ is described in this theory using the following differential equation:

$$
\frac{d Q}{d t}=\underbrace{C_{1} Q^{\frac{5}{4}}}_{\text {channel enlargement }}-\underbrace{C_{2} Q\left(p_{\mathrm{i}}-p_{\mathrm{w}}\right)^{3}}_{\text {channel closure }},
$$

$p_{\mathrm{i}}$ and $p_{\mathrm{w}}$ are the ice and water pressure, $C_{1}$ and $C_{2}$ are constants depending on the geometry of the glacier and physical properties of ice and water. This equation states that the time evolution of discharge is governed by two opposing processes, one of which causes enlargement of the channel, the other of which causes closure. The channel enlarges because the ice of the channel wall melts due to dissipation of potential energy, whereas closure occurs because the ice creeps inward to fill the void. The steady state of this equation is unstable, thus, either a channel will enlarge progressively and lead to an outburst flood or it is sealed. This same behaviour is shared by the full theory (Nye, 1976) and by its extension (Spring and Hutter, 1982) also including the water temperature of the lake which can greatly affect peak discharge.

\section{Modelled lake outbursts}

We employed Clarke's (2003) model, which uses a modified version of the Spring-Hutter equations, to simulate the outburst floods of the lake on Unterer Grindelwaldgletscher. The modifications of the Spring-Hutter equations are minor, such that they become numerically stable. This model, unlike the simpler one presented in the last section, includes water temperature as a variable which is important for our setting, as the lake water can be quite warm. As input, the model needs the geometry of the bed, ice and channel (Fig. 6), the hypsometry of the lake basin (derived from photogrammetry and future estimates, Fig. 5), the lake temperature $T$ and the roughness of the channel $n_{\text {man }}$. The model uses the Manning roughness description which relates water flow speed to the pressure difference (Chow et al., 1998). Initial conditions are the water-level of the lake and the channel size. The boundary condition is the water pressure at the glacier terminus (cf. Fig. 6), i.e. the height of the water-level inside the gorge. The model then calculates the time evolution of the channel diameter, discharge and lake level.

We first ran the model for the 2008 outburst. For that outburst, we have measurements of the lake level, bathymetry (therefore, also lake discharge), proglacial discharge and lake temperature $T$. We fitted the model to the hydrograph by varying $n_{\text {man }}$. Hydrographs for the potential outburst in the years 2009-2014 were calculated by assuming the predicted lake bathymetry and using the same $n_{\operatorname{man}}$ and $T$ as for 2008 . The parameters $n_{\operatorname{man}}$ and $T$ are poorly constrained and we analysed the sensitivity of the model for a range of those parameters for the expected 2014 flood. Furthermore, in the case of large outburst floods, the narrow gorge (Fig. 6) has a damming effect and causes the water-level in the gorge to rise. The resulting back pressure lowers the lake discharge. We did not model the flood routing in the gorge, which would be needed to calculate the water-level at the glacier terminus. Instead, a simple sensitivity analysis for the 2014 flood was performed by prescribing several fixed water-levels in the gorge as lower boundary condition, ranging from $0 \mathrm{~m}$ to $200 \mathrm{~m}$.

\subsection{Outburst 2008}

The first serious outburst flood occurred in 2008. The lake filled during spring and on 30 May it drained within a few hours, attaining a peak discharge of $80 \mathrm{~m}^{3} \mathrm{~s}^{-1}$. At the onset of the outburst, the lake was barely half full, having a volume of $0.75 \times 10^{6} \mathrm{~m}^{3}$. Afterwards, during the summer 2008 , the lake basin remained empty most of the time but in August it suddenly refilled within a few hours. This suggests that water was entering the lake from the subglacial drainage system as supraglacial streams entering the lake could not have filled it as rapidly. However, in August the lake did not empty fast enough to cause another flood.

We fitted the outburst flood model to the discharge hydrographs of both of the lake and of the proglacial stream of the May 2008 outburst (Fig. 8). It is clear that the model is far from perfect, with the measured hydrograph rising more quickly than the modelled one. Nevertheless, it correctly reproduces the peak proglacial discharge.

\subsection{Future outbursts}

With the parameters obtained from fitting the model to the 2008 outburst, we ran the model for the known bathymetries of 2008 and 2009 and for the ones predicted for the years 2010-2014, assuming a completely filled lake and, of course, an identical outburst mechanism. Figure 9 shows the calculated hydrographs; they are similar to each other but have an increasing peak discharge.

We calculated an advance warning time $\Delta t$ by assuming that an alarm can be raised once the lake level has dropped by $0.5 \mathrm{~m}$, and then calculated the time until lake discharge reached $80 \mathrm{~m}^{3} \mathrm{~s}^{-1}$ when damage would start to occur (cf. Sect. 7.3). In Fig. 10, the maximal discharge $Q_{\max }$ and $\Delta t$ is plotted against the year of the flood. $Q_{\max }$ increases from 130 to $590 \mathrm{~m}^{3} \mathrm{~s}^{-1}$ and $\Delta t$ decreases from $5.5 \mathrm{~h}$ down to $3.3 \mathrm{~h}$. 


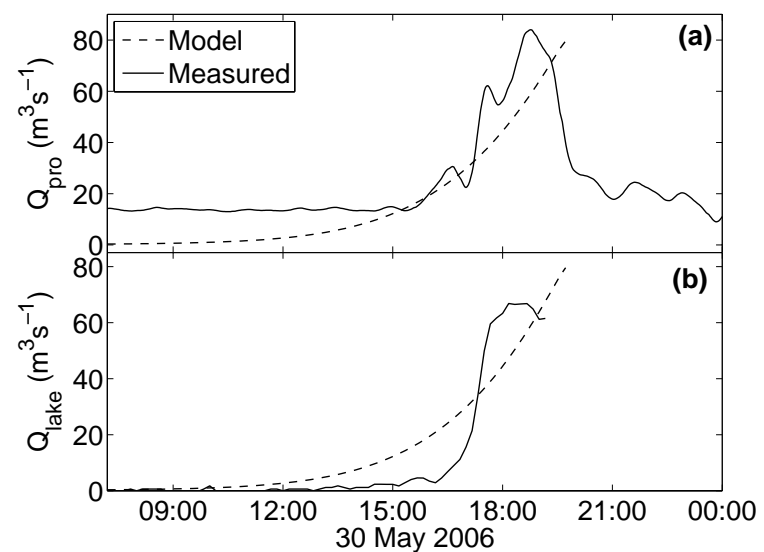

Fig. 8. Comparison of the measured and modelled outburst hydrographs in May 2008. (a) proglacial discharge, (b) lake discharge (note that when the $Q_{\text {lake }}$ time series stops, the lake is not empty yet). Model parameters: lake volume $0.75 \times 10^{6} \mathrm{~m}^{3}$, lake water temperature $2.0^{\circ} \mathrm{C}$, Manning channel roughness $0.025 \mathrm{~m}^{-1 / 3} \mathrm{~s}$.

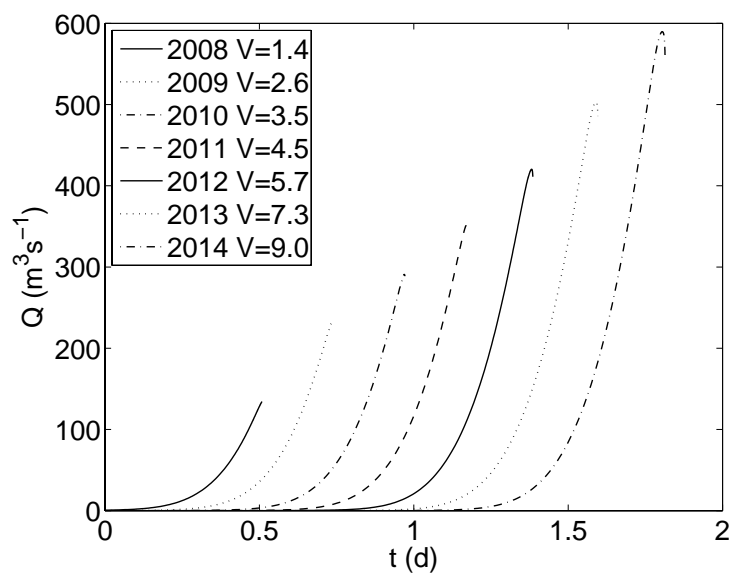

Fig. 9. Predicted outburst hydrographs at the glacier terminus for the years 2008-2014 assuming a completely filled lake basin and using model parameters as in Fig. 8. The timing is only relative and the hydrographs are offset for ease of viewing. The legend gives the year and the lake volume $V\left(10^{6} \mathrm{~m}^{3}\right)$.

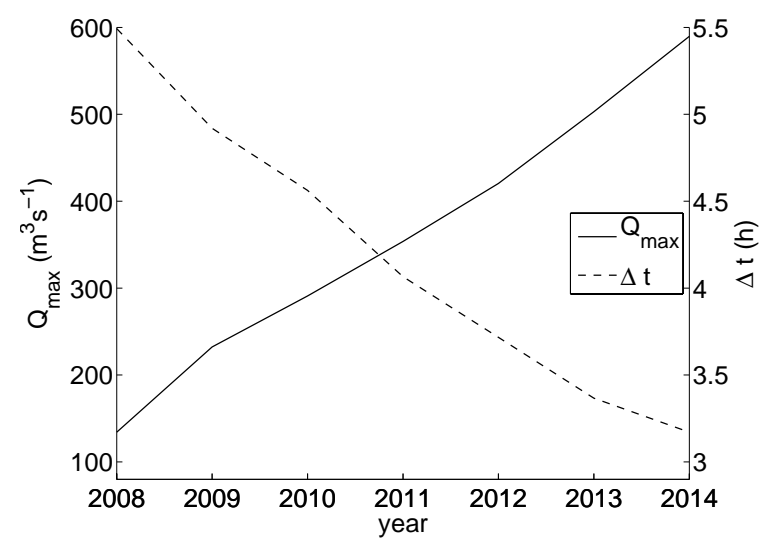

Fig. 10. Predicted maximal discharge $\left(Q_{\max }\right)$ and advance warning time $(\Delta t)$ for the years 2008-2014 assuming a completely filled lake basin and model parameters as used for Fig. 8.
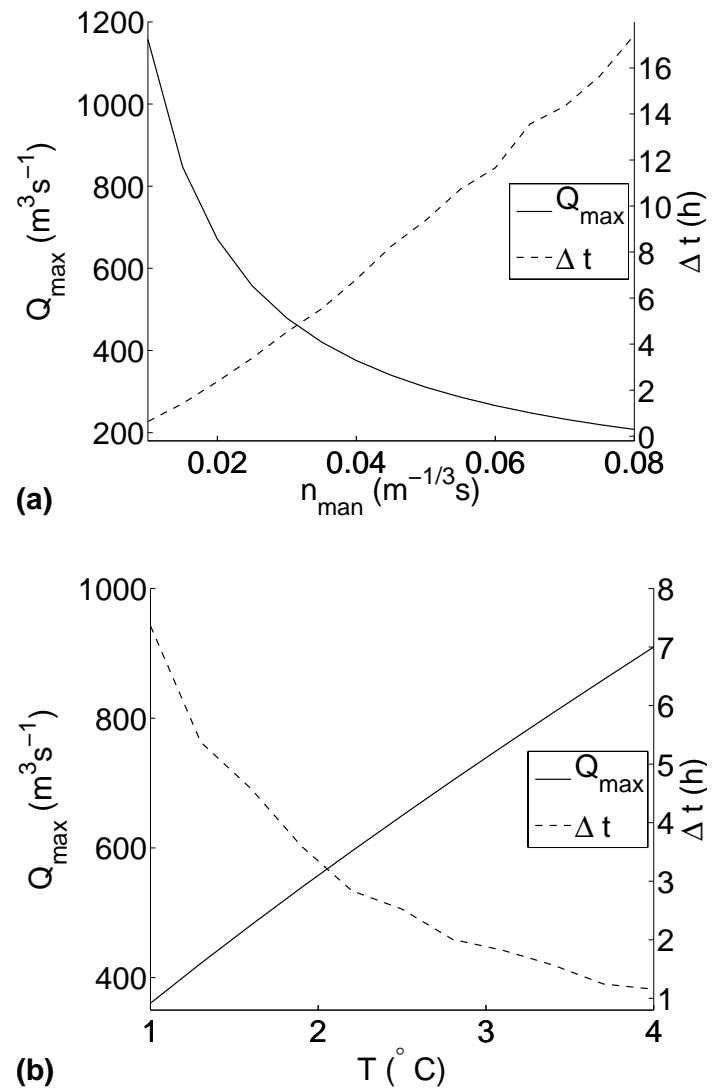

Fig. 11. The model sensitivity (a) to changes in Manning channel roughness $n_{\text {man }}$ and (b) to changes in the lake water temperature $T$. Left axis gives maximal discharge $Q_{\max }$ and right axis advance warning time $\Delta t$.

The two model parameters, channel roughness $n_{\operatorname{man}}$ and lake temperature $T$, are likely to vary from year to year. We took the model run for 2014 as base case with $T=2.0^{\circ} \mathrm{C}$ and $n_{\text {man }}=0.025 \mathrm{~m}^{-1 / 3} \mathrm{~s}$ and varied either $T$ or $n_{\text {man }}$ to study the sensitivity of the model to these parameters. Figure 11a shows plots of $Q_{\max }$ and $\Delta t$ against $n_{\operatorname{man}}$. $Q_{\max }$ decreased considerably from 1200 to $220 \mathrm{~m}^{3} \mathrm{~s}^{-1}$ with $n_{\operatorname{man}}$ increasing from 0.01 to $0.08 \mathrm{~m}^{-1 / 3} \mathrm{~s}$ and, thus, $\Delta t$ increased from 0.6 to $17 \mathrm{~h}$. Figure $11 \mathrm{~b}$ shows that $Q_{\max }$ increased from 380 to $960 \mathrm{~m}^{3} \mathrm{~s}^{-1}$ with $1<T<4^{\circ} \mathrm{C}$, and, thus, $\Delta t$ decreased from 7.5 to $1.1 \mathrm{~h}$.

The gorge is very narrow $(\sim 0.5 \mathrm{~m})$ near the terminus of the glacier which causes the water-level to rise considerably at high discharge, thus, exerting a back pressure on the water flowing inside the glacier. Taking the same base case as above, we increased the water-level in the gorge from 0 to $200 \mathrm{~m}$. This decreased $Q_{\max }$ (Fig. 12) from 600 to $320 \mathrm{~m}^{3} \mathrm{~s}^{-1}$ and consequently $\Delta t$ increased from 3.2 to $7.3 \mathrm{~h}$. 


\section{Discussion}

The lake basin, which formed on the tongue of Unterer Grindelwaldgletscher, will increase in volume in the future and, thus, presents an ever-growing threat to the community of Grindelwald and others further downstream. The proglacial stream, Weisse Lütschine, flows through Grindelwald Grund, where the terminal station of the Jungfraubahnen is located in addition to other infrastructure. Firstly, we discuss the model performance, then we assess the hazard potential of the lake for floods in Grindelwald based on model results, and recommend strategies for averting damage to people and infrastructure.

\subsection{Choice of outburst flood model}

There are two reasons we chose to use Clarke's (2003) model: firstly, this model and its predecessors are established models of glacier lake outburst floods and have been applied to several different outbursts (Nye, 1976; Clarke, 1982, 2003) which showed that they can perform adequately. Secondly, a more physically complex model would have been difficult to construct and run because of the following factors. The exact physical details responsible for the outbursts are poorly known and they would be difficult to experimentally investigate. Furthermore, the responsible mechanisms can vary between drainage events as is illustrated by the lake drainages in 2008: once it drained rapidly and once slowly, without producing a flood. Also, a more complex model would likely require more input data like, e.g., the geometry of the glacier bed or the sediment layer thickness at the bed. However, measurements of these quantities are not feasible.

Thus, the results of this study are only valid for one of the many possible drainage mechanism and its resulting hazard potential. We think that the modelled mechanism, or slight variations thereof as discussed below, can produce the potentially largest outburst floods in the time frame considered in this study. Therefore, it is the relevant mechanism to be considered for the presented hazard evaluation.

\subsection{Model performance}

The outburst in 2008 gave us a chance to calibrate the unknown channel roughness parameter $n_{\text {man }}$ by fitting the modelled to the measured hydrograph. Figure 8 shows that the fit is not so accurate, in particular the lake outflow hydrograph rises much faster than the modelled one. This could be due to a number of factors and their combination: (a) we know that there is an already existing subglacial drainage system in place conducting the surface meltwater to the glacier terminus (see Fountain and Walder, 1998, for a review of the glacial drainage system). Figure 6 shows the main drainage system channel (annotated by subglacial channel) and the channel connecting the lake to it (annotated by englacial channel). At the beginning of the outburst only the connec-

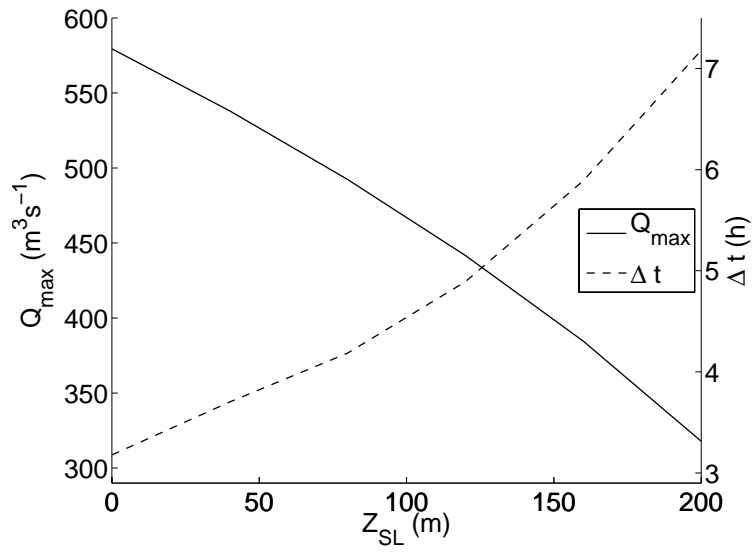

Fig. 12. The model sensitivity to changes in water-level in the gorge $Z_{\mathrm{SL}}$. Change in maximal discharge (left axis), change in advance warning time (right axis).

tion channel would have to open up, which it could do much faster due to its shorter length. Once the lake discharge surpasses the capacity of the main drainage system, the channel of the main drainage system will have to enlarge too. Thus, this mechanism would lead to a faster-rising hydrograph at the onset of the flood and to a slightly higher peak discharge. (b) The onset of the lake outflow could be due to a crevasse opening and connecting to the subglacial drainage system, which would lead to an even faster increase in initial discharge than the triggering mechanism (a).

Especially at higher discharges, as can be expected in the years after 2010, the narrow geometry of the gorge below the terminus of the lake will influence the lake discharge hydrograph. Results show that the channel can attain a maximum diameter of $\sim 12 \mathrm{~m}$ for the highest discharge values. If the width of the gorge segment, which is still underneath the glacier, is less than this maximal channel diameter (at least in places), then the emptying of the lake will take place more slowly and the peak discharge will be reduced compared to normal conditions. It is not feasible to quantify this effect but it is likely to be minor compared to the other influences (e.g. lake water temperature, discussed below). In the ice-free part near the glacier terminus, the gorge narrows to $\sim 0.5 \mathrm{~m}$. As a result, with increasing discharge, the water-level in the gorge at the glacier terminus will rise above the level of the subglacial channel. In this case, the water pressure head at the end of the subglacial channel does not, as previously assumed, correspond to atmospheric pressure but to the water-level in the gorge. We estimate the maximal water-level in the gorge for the 2014 outburst using the following argument: the calculated cross-section of the subglacial channel at the glacier terminus has a maximum area of $50 \mathrm{~m}^{2}$. If the flow velocity of water in the adjoining $0.5 \mathrm{~m}$ wide gorge remains the same as in the subglacial 
channel, then the height of the free water-level has to be $\sim 100 \mathrm{~m}$ above the level of the channel at the terminus. The exerted back pressure diminishes calculated peak discharge (Fig. 12) from 600 to $450 \mathrm{~m}^{3} \mathrm{~s}^{-1}$ for a water-level of $100 \mathrm{~m}$ in the gorge.

The two important model parameters of channel roughness $n_{\text {man }}$ and lake temperature $T$ are not well constrained. For the first, we cannot estimate its band of variation as we have only witnessed one outburst flood so far. The latter is dependent on the weather conditions prior to the flood and on how much ice is exposed inside the lake basin. Thus, we conducted a sensitivity analysis of the model based on the model run of 2014 for quite a wide range of these parameter (Fig. 11), which shows that both parameters have a major effect on both the modelled peak discharge $Q_{\max }$ and advance warning time $\Delta t$. Based on our current knowledge, it seems prudent to assume a value of $n_{\operatorname{man}}$ in the range $0.015<n_{\operatorname{man}}<0.045 \mathrm{~m}^{-1 / 3} \mathrm{~s}\left(0.025 \mathrm{~m}^{-1 / 3} \mathrm{~s}\right.$ in 2008) which leads to a considerably uncertainty of the calculated $Q_{\max }$ between 800 and $350 \mathrm{~m}^{3} \mathrm{~s}^{-1}$. The lake temperature can and should be measured and high values will indicate the danger of a more intense outburst. The temperature range $1<T<4{ }^{\circ} \mathrm{C}$ is realistic for the lake $\left(2{ }^{\circ} \mathrm{C}\right.$ in 2008) which leads to a range of calculated $380<Q_{\max }<960 \mathrm{~m}^{3} \mathrm{~s}^{-1}$ in 2014. Note that a higher $Q_{\max }$ automatically means a shorter $\Delta t$ due to the shorter duration of the whole flood and, thus, outbursts with a greater damage potential also have shorter advance warning times.

The uncertainties in the model predictions are considerable. However, at the moment, with only one observed outburst flood, nothing would be gained by applying a more complicated model, e.g. taking the above-mentioned processes (a) and (b) into account. The ongoing lowering of the lake basin will make the connection channel to the main drainage system shorter and, thus, item (a) is likely to become more important in the future.

The time of the outburst and the lake level at that point cannot be predicted based on any current theories and it is likely that this will remain so (Werder, 2009). Thus, it is possible that the basin on Unterer Grindelwaldgletscher will never fill completely before drainage initiates and, thus, peak discharges will remain below what we have predicted.

\subsection{Hazard assessment for Grindelwald}

The flood defences of the Weisse Lütschine have been constructed to safely conduct discharges of up to $120 \mathrm{~m}^{3} \mathrm{~s}^{-1}$ of which typically $40 \mathrm{~m}^{3} \mathrm{~s}^{-1}$ are due to background discharge. Thus, excluding times of already heightened discharge of the Weisse Lütschine due to strong precipitation, a peak lake discharge of $80 \mathrm{~m}^{3} \mathrm{~s}^{-1}$ can be conducted without leading to damage. This is the peak discharge of the 2008 outburst and, thus, it is evident that a larger lake basin, already one of the size expected in 2009 , poses a considerable threat to Grindelwald, as damage will occur at higher discharge and people will need to be evacuated. Thus, peak discharge $Q_{\max }$ prediction and also, for evacuation purposes, the advance warning time $\Delta t$ estimates are necessary. For the flood in 2008, the measured $\Delta t$ is $02: 05 \mathrm{~h}$ and the calculated one is $7 \mathrm{~h}$. This shows, as discussed in the previous section (processes (a) and (b)), that the flood rises faster in the initial stages than predicted by the model. Thus, all the advance warning times should be divided by a safety factor of three. A complementary early warning system could be based on measurements of the subglacial water pressure, which increases rapidly as an outburst commences. It could support the primary system which relies on data from lake level measurements.

As of spring 2009, Grindelwald will have to anticipate major damage to its infrastructure from floods due to the lake. The exact peak discharge cannot be determined as we cannot predict the filling level at which an outburst will occur (it is most likely somewhat random). Furthermore, we cannot predict how many outburst floods will occur per year as the lake can refill after emptying, as illustrated by the episode in $\mathrm{Au}-$ gust 2008. All in all, we estimate the likelihood of a major flood as being very high. Furthermore, in the years beyond 2010, the potential discharges are large enough to inflict very serious damage in all downstream communities.

\subsection{Preventive measures}

From spring 2008 onwards, the expected floods due to the drainage of the glacier lake were estimated to cause damages in the Lütschental as well as further downstream. An early warning system has been installed in the glacier lake, which continuously records the lake water-level with a water pressure sensor. As soon as a critical lake level decrease is recorded, a warning message is automatically sent to the person in charge of the regional natural hazard prevention. This system worked perfectly during the flood of the lake drainage on 30 May 2008.

To avert future destructive floods, the lake level should be kept as low as possible such that the potential lake water volume remains small $\left(<0.5\right.$ million $\left.\mathrm{m}^{3}\right)$. To achieve this goal, the Bernese authorities decided to build a $2.1-\mathrm{km}$ long drainage tunnel on the right side of the gorge from Marmorbruch to the lake (Fig. 1). The tunnel will exit onto the glacier surface behind the debris-covered ice dam at the lowest possible level, so that the water of the lake can drain through the tunnel. The anticipated completion date is October 2009. It is planned to regularly adjust the tunnel exit to the lowering glacier surface in the following years. The tunnel is designed to allow large construction machines to reach the glacier to artificially level the surface in order to allow water to drain through the tunnel or to make a breach in the debris-covered ice dam, in the event that such measures prove necessary in the future. The early warning system and the tunnel construction work are described on the website http://www.gletschersee.ch. 


\section{Conclusions}

New natural hazards can emerge due to the retreat of glaciers, as in the case of Unterer Grindelwaldgletscher where a new supraglacial lake has recently formed. This ice-dammed lake is unstable and can drain rapidly, leading to dangerous floods. We conducted a hazard assessment of the lake on Unterer Grindelwaldgletscher and predicted ranges of future maximal lake volume, flood discharge and advance warning times.

The latter were shown to be long enough so that, with a suitable alarm system, a timely evacuation should be feasible. However, from 2009 onward, floods with a high potential for destruction are to be anticipated and, thus, the construction of a $2.1-\mathrm{km}$ long drainage tunnel was initiated in order to limit the lake volume below a critical level.

Acknowledgements. This study is a result of hazard assessment efforts requested by the authorities of the Canton of Berne who also provided the proglacial discharge data. The salary of M. A. Werder was funded by the Swiss National Science Foundation, Grant-No. 200021-103882/1 and 200020-111892/1. Thanks are due to Hermann Bösch for having prepared the DTMs and orthophotos. We also thank Swisstopo and Rolf Hübscher for aerial photographic surveys. Garry K. C. Clarke provided his computer program to model the Spring-Hutter equations, and Susan Braun-Clarke proofread the English. We are grateful to the editor J. M. Vilaplana and the two reviewers F. J. Navarro and J. Walder for their thoughtful comments and suggestions.

Edited by: J. M. Vilaplana

Reviewed by: F. Navarro and J. Walder

\section{References}

Bauder, A., Funk, M., and Huss, M.: Ice volume changes of selected glaciers in the Swiss Alps since the end of the 19th century, Ann. Glaciol., 46, 145-149, 2007.

Benn, D. I., Wiseman, S., and Hands, K. A.: Growth and drainage of supraglacial lakes on debrismantled Ngozumpa Glacier, Khumbu Himal, Nepal, J. Glaciol., 47, 626-638, 2001.

Chow, V., Maidment, D., and Mays, L.: Applied Hydrology, McGraw-Hill Series in Water Resources and Environmental Engineering, McGraw-Hill, New York, 1998.

Clarke, G. K. C.: Glacier outburst floods from "Hazard Lake", Yukon Territory, and the problem of flood magnitude prediction, J. Glaciol., 28, 3-21, 1982.

Clarke, G. K. C.: Hydraulics of subglacial outburst floods: new insights from the Spring-Hutter formulation, J. Glaciol., 49, 299313, 2003.

Flowers, G., Björnsson, H., Pálsson, F., and Clarke, G.: A coupled sheet-conduit mechanism for jökulhlaup propagation, Geophys. Res. Lett., 31, L05401, doi:doi:10.1029/2003GL019088, 2004.

Fountain, A. G. and Walder, J. S.: Water flow through temperate glaciers, Rev. Geophys., 36, 299-328, 1998.
Glaciological reports: The Swiss Glaciers, 1880-2004/05, Tech. Rep. 1-124, Yearbooks of the Cryospheric Commission of the Swiss Academy of Sciences (SCNAT), published since 1964 by Laboratory of Hydraulics, Hydrology and Glaciology (VAW) of ETH Zürich, available at: http://glaciology.ethz.ch/ swiss-glaciers/, 1881-2009.

Gulley, J. and Benn, D.: Structural control of englacial drainage systems in Himalayan debris-covered glaciers, J. Glaciol., 53, 399-412, 2007.

Haeberli, W.: Frequency and characteristics of glacier floods in the Swiss Alps, Ann. Glaciol., 4, 85-90, 1983.

Lundstrom, S., McCafferty, A., and Coe, J.: Photogrammetric analysis of 1984-89 surface altitude change of the partially debris-covered Eliot Glacier, Mount Hood, Oregon, USA, Ann. Glaciol., 17, 167-170, 1993.

Ng, F. S. L. and Björnsson, H.: On the Clague-Mathews relation for jökulhlaups, J. Glaciol., 49, 161-172, 2003.

Nye, J. F.: Water flow in glaciers: jökulhlaups, tunnels and veins, J. Glaciol., 17, 181-207, 1976.

Oppikofer, T., Jaboyedoff, M., and Keusen, H. R.: Collapse at the eastern Eiger flank in the Swiss Alps, Nat. Geosci., 1, 531-535, doi:1038/ngeo258, 2008.

Raymond, M., Wegmann, M., and Funk, M.: Inventar gefährlicher Gletscher in der Schweiz, Mitteilung 182, Versuchsanstalt für Wasserbau, Hydrologie und Glaziologie der ETH Zürich, 2003.

Roberts, M. J.: Jökulhlaups: a reassessment of floodwater flow through glaciers, Rev. Geophys., 43, RG1002, doi:10.1029/2003RG000147, 2005.

Röthlisberger, H.: Eislawinen und Ausbrüche von Gletscherseen, in: Gletscher und Klima - glaciers et climat, Jahrbuch der Schweizerischen Naturforschenden Gesellschaft, wissenschaftlicher Teil 1978, 170-212, edited by: Kasser, P., Birkhäuser Verlag Basel, Boston, Stuttgart, 1981.

Spring, U. and Hutter, K.: Conduit flow of a fluid through its solid phase and its application to intraglacial channel flow, Int. J. Eng. Sci., 20, 327-363, 1982.

Steiner, D., Zumbühl, H. J., and Bauder, A.: Two Alpine glaciers over the last two centuries: a scientific view based on pictorial sources, in: The Darkening Peaks: Glacier Retreat, Science, and Society, edited by: Orlove, B., Wiegandt, E., and Luckman, B., University of California Press, international and Interdisciplinary Workshop on Mountain Glaciers and Society, held in Wengen, Switzerland, 6-8 October 2004, 83-99, 2008.

Tweed, F. S. and Russell, A. J.: Controls on the formation and sudden drainage of glacier-impounded lakes: implications for jökulhlaup characteristics, Prog. Phys. Geog., 23, 79-110, 1999.

VAW: Unterer Grindelwaldgletscher, Glaziologische Abklärungen im Zusammenhang mit der Seebildung, Bericht im Auftrag des Oberingenieurkreis I des Kantons Bern, Nr. 7945.21.2, unpublished, 2007.

Werder, M. A.: Dye tracing and modelling jökulhlaups, Ph.D. thesis, ETH Zürich, no. 18293, 2009.

Zumbühl, H.: Die Schwankungen der Grindelwaldgletscher in den historischen Bild- und Schriftquellen des 12. bis 19. Jahrhunderts, Denkschriften der Schweizerischen Naturforschenden Gesellschaft, 92, 279 S. + Anhang, 1980. 